\title{
PROFIL PENDERITA ALERGI DENGAN HASIL SKIN PRICK TEST TDR POSITIF DI POLIKLINIK ALERGI-IMUNOLOGI RSUP PROF. DR. R. D. KANDOU MANADO PERIODE 2007-2009
}

\author{
${ }^{1}$ Novitasari \\ ${ }^{2}$ Angle Sorisi \\ ${ }^{2}$ G.J.P Wahongan \\ ${ }^{1}$ Kandidat Skripsi Fakultas Kedokteran Universitas Sam Ratulangi Manado \\ ${ }^{2}$ Bagian Parasitologi Universitas Sam Ratulangi Manado \\ Email: novitasari09302@yahoo.com
}

\begin{abstract}
House dust mites are inhaled allergens and as a trigger of the onset of allergic diseases such as bronchial asthma, atopic dermatitis, conjunctivitis, and alergic rhinitis. Mites are the major allergenic components from house dust. House dust mite section containing allergens in the cuticle, the sex organs and the gastrointestinal tract. Approximately $80 \%$ of patients allergic to house dust mites have specific IgE antibodies against group I and II allergens that clinically associated with asthma, atopic dermatitis, alergic rhinitis. This IgE can be detected in serum by immune assay or on the skin with a skin allergy test. Purpose: To provide a profil picture of allergy with the result of skin prick test positive to housedust mites in allergy - immunology clinic medicine in public hospital Prof. Kandou period 2007 - 2009. Method and results: This study uses a retrospective descriptive method trough medical records at the allergy- immunology clinic in public hospital Prof. Kandou period 2007 - 2009. Result of this study, the number of allergy sufferers with positive results of skin prick test of house dust mite is 136 patients, with the highest prevalence in 2008. Earned women more than men, highest in the age group 51 - 60 years, most patients work as civil servants, and most diagnosis was found is bronchial asthma.
\end{abstract}

Keywords: house dust mite, allergy, skin prick test.

Abstrak: Tungau Debu Rumah (TDR) merupakan alergen hirup dan sebagai faktor pencetus timbulnya penyakit alergi seperti asma bronkial, dermatitis atopik, konjungtivitis, dan rinitis alergik. $^{1-4}$ Tungau merupakan komponen alergenik utama dari debu rumah. Bagian TDR yang mengandung alergen adalah kutikula, organ seks dan saluran cerna. ${ }^{1-3}$ Kurang lebih $80 \%$ penderita alergi TDR mempunyai antibodi IgE spesifik terhadap alergen kelompok I dan II yang secara klinis berkaitan dengan penyakit asma, dermatitis atopik, dan rinitis alergika. ${ }^{2}$ IgE ini dapat dideteksi dalam serum melalui immune assay atau pada kulit dengan tes kulit alergi. ${ }^{6}$

Tujuan: Untuk memberikan gambaran mengenai profil penderita alergi dengan hasil skin prick test TDR positif di Poliklinik Alergi-Imunologi RSUP Prof. Dr. R. D. Kandou periode 20072009. Metode dan Hasil: Penelitian ini menggunakan metode retrospektif deskriptif melalui rekam medik di Poliklinik Alergi-Imunologi RSUP Prof. Dr. R. D. Kandou Manado Periode 2007-2009. Dari hasil penelitian ini didapatkan Jumlah penderita alergi dengan hasil skin prick test TDR positif $(+)$ sebanyak 136 penderita, dengan prevalensi terbanyak pada tahun 2008. Didapatkan perempuan lebih banyak dibandingkan laki-laki, terbanyak pada kelompok usia 5160 tahun, sebagian besar penderita berprofesi sebagai (PNS), dan diagnosis terbanyak yang ditemukan adalah asma bronkial.

Kata Kunci: TDR, Alergi, Skin Prick Test. 
Tungau Debu Rumah (TDR) merupakan alergen hirup dan sebagai faktor pencetus timbulnya penyakit alergi seperti asma bronkial, dermatitis atopik, konjungtivitis, dan rinitis alergik. $^{1-4}$ Tungau merupakan komponen alergenik utama dari debu rumah. Bagian TDR yang mengandung alergen adalah kutikula, organ seks dan saluran cerna. $^{1-3}$

Kurang lebih $80 \%$ penderita alergi TDR mempunyai antibodi IgE spesifik terhadap alergen kelompok I dan II yang secara klinis berkaitan dengan penyakit asma, dermatitis atopik, dan rinitis alergika. ${ }^{2}$

Peranan TDR terhadap asma bronkial sudah tidak diragukan lagi. Penelitian epidemiologis Dowse et al menunjukan TDR berperan sangat penting pada kenaikan prevalensi asma di South Fore, Papua New Guinea. Bila 10 tahun sebelumnya di daerah tersebut hanya didapatkan prevalensi asma sebesar 0,28\%, maka saat diteliti Dowse et al telah menjadi $7,3 \% .^{3}$ Penelitian yang dilakukan oleh German Multi Center Atopy (MAS) menyebutkan bahwa terdapat hubungan erat antara sensitivitas tungau dengan mengi. ${ }^{3}$

Di Indonesia 90\% penderita asma rentan terhadap debu rumah dan TDR. Di Jepang, penderita yang rentan tercatat 70\%80\%. Di Australia, 90\% anak-anak yang menderita asma juga alergi terhadap TDR. Dari angka-angka tersebut dapat dilihat bahwa penderita asma umumnya mempunyai tingkat kepekaan tinggi terhadap TDR. $^{3}$

Debu rumah, bagi sebagian kelompok orang tertentu merupakan komponen alergen inhalan yang penting karena berperan terhadap timbulnya reaksi alergi. ${ }^{2}$

Di dalam debu rumah terdapat TDR. TDR ini banyak ditemukan pada rumah yang lembab, kasur, bantal, guling, karpet serta berbagai perabot rumah yang lain. Populasi TDR terbanyak didapatkan pada debu kamar tidur terutama pada debu kasur. $^{1-3}$ Selain di dalam rumah, TDR juga ditemukan di luar rumah, misalnya pada sarang burung, permukaan kulit mamalia dan binatang lainnya. Makanannya adalah serpihan kulit (skuama) manusia/binatang. ${ }^{1}$
Lopo C (2003) dalam penelitiannya di Makassar melaporkan jenis alergen yang paling banyak positif pada tes cukit kulit adalah debu rumah $(77,27 \%)$ dan tungau debu rumah (54,55\%). Sedangkan penelitian Alimah Y (2005) melaporkan jenis alegen inhalan positif yang terbanyak yaitu debu rumah sebesar (60\%) dan tungau debu rumah (75\%). Pada unit rawat jalan Alergi Imunologi THT RS dr Wahidin Sudirohusodo Makassar selama 2 tahun (2005-2006) didapatkan alergen inhalan terbanyak adalah tungau debu rumah sebesar (75,6\%), disusul dengan debu rumah sebesar $(42 \%){ }^{5}$

Immunoglobulin E merupakan mediator pada hipersensitivitas tipe cepat termasuk asma, rinitis alergi dan dermatitis atopik. Kondisi ini merupakan hasil interaksi antara alergen, IgE spesifik, mast sel atau basofil yang menyebabkan terjadinya perubahan pada membran sel. Immunoglobulin E ini dapat dideteksi dalam serum melalui immune assay atau pada kulit dengan tes kulit alergi. ${ }^{5}$

\section{METODE PENELITIAN}

Jenis penelitian ini bersifat retrospektif deskriptif dengan menggunakan data sekunder. Populasi pada penelitian ini adalah pasien alergi yang pernah berobat di poliklinik Alergi-Imunologi RSUP Prof. Dr. R. D. Kandou periode 2007-2009. Besar sampel yang diteliti adalah pasien alergi yang hasil skin prick test TDR positif $(+)$. Instrumen penelitian adalah Catatan rekam medik seluruh pasien alergi di poliklinik Alergi-Imunologi SMF Ilmu Penyakit Dalam RSUD Prof. Dr. R. D. Kandou periode 2007-2009

\section{HASIL DAN PEMBAHASAN}

Berdasarkan penelitian yang dilakukan di poliklinik Alergi-Imunologi RSUP Prof. Dr. R. D. Kandou Manado periode 20072009, di dapatkan 136 kasus pasien Alergi dengan hasil Skin Prick Test Positif $(+)$ yang dijadikan sampel penelitian. Hasil yang telah diperoleh di susun dalam bentuk tabel sebagai berikut: 
1016 Jurnal e-Biomedik (eBM), Volume 1, Nomor 2, Juli 2013, hlm. 1014-1018

Tabel 1. Distribusi pasien Alergi berdasarkan Tahun Kejadian

\begin{tabular}{ccc}
\hline TAHUN & JUMLAH & PERSEN \\
\hline 2007 & 46 & $33,82 \%$ \\
2008 & 52 & $38,24 \%$ \\
2009 & 38 & $27,94 \%$ \\
\hline TOTAL & 136 & $100 \%$
\end{tabular}

Berdasarkan tabel diatas, dapat diketahui bahwa pasien penderita Alergi terbanyak terdapat pada tahun 2008 sebanyak 52 pasien (38\%), dibandingkan dengan tahun 2007 sebanyak 46 pasien (34\%) dan tahun 2009 sebanyak 38 pasien (28\%).

Tabel 2. Distribusi pasien Alergi berdasarkan Jenis Kelamin

\begin{tabular}{ccc}
\hline JENIS KELAMIN & JUMLAH & PERSEN \\
\hline Perempuan & 78 & $57,35 \%$ \\
Laki - Laki & 58 & $42,65 \%$ \\
\hline TOTAL & 136 & $100 \%$
\end{tabular}

Berdasarkan tabel diatas, dapat diketahui bahwa pasien penderita Alergi terbanyak adalah berjenis kelamin perempuan dengan jumlah penderita 78 orang (57\%), sedangkan laki-laki berjumlah 58 orang $(43 \%)$.

Tabel 3. Distribusi pasien Alergi berdasarkan Umur

\begin{tabular}{ccc}
\hline UMUR & JUMLAH & PERSEN \\
\hline$<21$ & 5 & $3,68 \%$ \\
$21-30$ & 8 & $5,88 \%$ \\
$31-40$ & 18 & $13,24 \%$ \\
$41-50$ & 29 & $21,32 \%$ \\
$51-60$ & 38 & $27,94 \%$ \\
$61-70$ & 24 & $17,65 \%$ \\
$>70$ & 14 & $10,29 \%$ \\
\hline TOTAL & 136 & $100 \%$
\end{tabular}

Berdasarkan Tabel diatas dapat diketahui bahwa penderita alergi terbanyak terdapat pada kelompok usia 51-60 tahun sebanyak 38 orang (27,94\%), diikuti kelompok usia 41-50 tahun sebanyak 29 orang (21,32\%), kemudian kelompok usia 61-70 tahun sebanyak 24 orang (17,65\%), kelompok usia 31-40 tahun sebanyak 18 orang $(13,24 \%)$, kelompok usia diatas 70 tahun sebanyak 14 orang (10,29\%), kelompok usia 21-30 tahun sebanyak 8 orang (5,88\%), dan kelompok usia $<21$ tahun sebanyak 5 orang (3,68\%).

Tabel 4. Distribusi pasien alergi menurut Pekerjaan

\section{PEKERJAAN JUMLAH PERSEN}

\begin{tabular}{lcc}
\hline PNS & 35 & $25,74 \%$ \\
Pensiunan & 34 & $25,00 \%$ \\
IRT & 29 & $21,32 \%$ \\
Swasta & 8 & $5,88 \%$ \\
Wiraswasta & 5 & $3,68 \%$ \\
Pelajar & 7 & $5,15 \%$ \\
Supir & 2 & $1,47 \%$ \\
Petani & 6 & $4,41 \%$ \\
Buruh & 1 & $0,74 \%$ \\
Tidak Ada & 9 & $6,62 \%$ \\
\hline \multicolumn{1}{c}{ TOTAL } & 136 & $100 \%$
\end{tabular}

Berdasarkan Tabel diatas dapat diketahui bahwa penderita alergi terbanyak bekerja sebagai PNS sebanyak 35 orang (25,74\%), pensiunan sebanyak 34 orang (25\%), IRT sebanyak 29 orang (21,32\%), swasta sebanyak 8 orang $(5,88 \%)$, wiraswasta sebanyak 5 orang $(3,68 \%)$, pelajar sebanyak 7 orang $(5,15 \%)$, supir sebanyak 2 orang (1,47\%), petani sebanyak 6 orang $(4,41 \%)$, buruh sebanyak 1 orang (0,74\%), dan tidak ada/tidak bekerja sebanyak 9 orang $(6,62 \%)$. 
Tabel 5. Distribusi pasien menurut Diagnosa Alergi dan Penyerta

DIAGNOSIS

JUMLAH PERSEN

\begin{tabular}{lcc}
\hline Asma Bronkhial & 41 & $30.15 \%$ \\
Alergi Obat & 22 & $16.18 \%$ \\
Rinithis Alergi & 12 & $8.82 \%$ \\
Alergi Makanan & 11 & $8.09 \%$ \\
Dermatitis Atopik & 10 & $7.35 \%$ \\
Suspect Alergi Obat & 7 & $5.15 \%$ \\
Asma Persisten Sedang & 4 & $2.94 \%$ \\
Bronkhitis Kronik & 3 & $2.21 \%$ \\
Batuk Kronis & 3 & $2.21 \%$ \\
Lain-lain & 16 & $11.76 \%$ \\
Tidak Ada & 7 & $5.15 \%$ \\
\hline \multicolumn{1}{c}{ TOTAL } & 136 & $100 \%$
\end{tabular}

Berdasarkan Tabel diatas dapat diketahui bahwa sebagian besar pasien terdiagnosa penyakit asma bronkial yaitu sebanyak 41 orang $(30,15 \%)$, kemudian 22 orang terdiagnosa alergi obat $(16,18 \%)$, rinitis alergi sebanyak 12 orang $(8,82 \%)$, alergi makanan sebanyak 11 orang $(8,09 \%)$, dermatitis atopik sebanyak 10 orang (7,35\%), suspect alergi obat sebanyak 7 orang (5,15\%), asma persisten sedang sebanyak 4 orang (2,94\%), bronchitis kronik sebanyak 3 orang (2,21\%), batuk kronis sebanyak 3 orang (2,21\%), lain-lain sebanyak 16 orang $(11,76 \%)$, dan tidak ada sebanyak 7 orang $(5,15 \%)$.

\section{BAHASAN}

Dari hasil penelitian yang diperoleh, pada tabel 1 dapat diketahui bahwa prevalensi penderita alergi dengan alergen tungau debu rumah positif $(+)$ pada tahun 2008 meningkat dari tahun sebelumnya. Hal ini menunjukan bahwa adanya penurunan penderita alergi pada tahun 2009. Berbeda dengan penelitian dari Alimah $\mathrm{Y}$ yang dikutip oleh Rahmawati $\mathrm{dkk}^{5}$ melaporkan jenis alergen inhalan positif yang terbanyak yaitu debu rumah sebesar (60\%) dan tungau debu rumah (75\%). Pada unit rawat jalan Alergi Imunologi THT RS dr Wahidin Sudirohusodo Makassar selama 2 tahun (2005-2006) didapatkan alergen inhalan terbanyak adalah tungau debu rumah sebesar $(75,6 \%)$ disusul oleh debu rumah sebesar $(42,1 \%)^{5}$

Dari 136 penderita alergi di poliklinik Alergi-Imunologi, penderita alergi terbanyak berjenis kelamin perempuan yaitu sebanyak 78 penderita $(57,35 \%)$, sisanya 58 orang $(42,65 \%)$ berjenis kelamin laki-laki. Hasil penelitian tersebut sejalan dengan beberapa penelitian yang menunjukan bahwa perempuan lebih banyak terkena alergi dibanding laki-laki. ${ }^{5,6}$ Namun, belum didapatkan perbedaan bermakna dari distribusi jenis kelamin. ${ }^{6}$

Berdasarkan distribusi penderita alergi menurut umur, insiden alergi terbanyak terdapat pada kelompok usia 51-60 tahun yaitu sebanyak 38 orang (27,94\%). Hal tersebut disebabkan karena paparan yang berulang dapat memicu timbulnya alergi pada seseorang, maka semakin bertambahnya usia seseorang, kemungkinan akan terkena alergi semakin meningkat pula. ${ }^{7}$ Untuk kasus asma, insidens tertinggi tampak pada kelompok umur $>10$ tahun, bila ditinjau dari kecenderungannya tampak peningkatan prevalensi pada kelompok umur yang makin besar. Pada kelompok umur yang lebih tua paparan terhadap alergen lingkungan makin meningkat dihubungkan dengan aktivitas luar rumah. ${ }^{6}$

Pada Tabel 4 didapatkan penderita alergi terbanyak berprofesi sebagai PNS (25,74\%) dan disusul dengan pensiunan (25,00\%) dan IRT (21,32\%). Profesi PNS lebih banyak karena rumah sakit tersebut merupakan rumah sakit rujukan bagi pengguna ASKES. Belum ada penjelasan secara pasti tentang hubungan pekerjaan dan alergi. Namun, penelitian kasus asma pada kelompok umur yang lebih tua paparan terhadap alergen lingkungan makin meningkat dihubungkan dengan aktivitas luar rumah. ${ }^{6}$ Sedangkan profesi sebagai IRT dapat kita hubungkan dengan seringnya terkena paparan alergen di dalam rumah saat membersihkan debu dan perabot rumah. 
Berdasarkan distribusi penderita berdasarkan diagnosis alergi dan penyerta tabel 5 didapatkan kasus alergi terbanyak terdiagnosis sebagai asma bronkial yaitu sebanyak 41 kasus (30,15\%). Prevalensi asma di seluruh dunia adalah sebesar $8-10 \%$ pada anak dan 3-5\% pada dewasa, dan dalam 10 tahun terakhir ini meningkat sebesar 50\%. Laporan kasus penyakit tidak menular pada Dinas Kesehatan Jawa Tengah khusus penderita asma bronkiale dari beberapa rumah sakit Kabupaten Kudus tahun 2005 sebanyak 6.315 penderita, tahun 2006 sebanyak 6.579 penderita, sedangkan pada tahun 2007 sampai pada bulan Maret sebanyak $2.958 .^{8}$

\section{SIMPULAN}

Jumlah penderita alergi dengan hasil skin prick test TDR positif $(+)$ periode 2007-2009 sebanyak 136 penderita. Prevalensi penderita alergi dengan tes cukit (skin prick test) alergen TDR positif $(+)$ meningkat pada tahun 2008. Sebagian besar penderita alergi dengan tes cukit (skin prick test) alergen TDR positif $(+)$ berjenis kelamin perempuan. Penderita alergi terbanyak berada pada kelompok usia 51-60 tahun. Sebagian besar penderita alergi berprofesi sebagai Pegawai Negeri Sipil (PNS). Sebagian besar penderita alergi dengan tes cukit (skin prick test) alergen TDR positif $(+)$ terdiagnosa asma bronkial. Disarankan untuk selalu menjaga kebersihan rumah dari debu dengan cara disapu dan dipel setiap hari, dan perabot rumah dibersihkan dengan dengan lap basah atau disedot dengan penyedot debu. Jangan membersihkan rumah dengan kemoceng, karena debu tidak hilang tetapi justru beterbangan.

\section{UCAPAN TERIMA KASIH}

Terima kasih kepada dr. Angle Sorisi, MSc selaku penguji 1, dr. G.J.P. Wahongan, MKes selaku penguji 2, dr. J. B.
Bernadus, Mbiomed selaku penguji 3, dan kepada semua pihak baik secara langsung maupun tidak langsung telah menumbuhkan ide atau gagasan pada penulis sehingga penulis dapat menyelesaikan artikel ini.

\section{DAFTAR PUSTAKA}

1. Susanto I, Ismid IS, Sjarifuddin PK, Sungkar S. Parasitologi Kedokteran. Departemen Parasitologi FKUI, Jakarta: 2009; 289-291.

2. Yudopranoto K. Perbandingan Populasi Tungau Debu Rumah Pada Kasur Kapuk dan Non-Kapuk di Perumahan PJKA kelurahan Randusari Semarang Selatan Jawa Tengah. Karya tulis ilmiah Fakultas Kedokteran Universitas Diponegoro, Semarang: 2006.

3. Sungkar S. Aspek Biomedis Tungau Debu Rumah. Maj Kedokt Indon, 2004;54 (6) : 224-32.

4. Thomas WR, Smith W. House-dust-mite allergens. Allergy 1998; 53: 821-832. Munksgaard: 1998.

5. Rahmawati, Punagi AQ, Savitri E. Hubungan Antara Beratnya Rinitis, Reaktivitas Tes Cukit Kulit dan Kadar Imunoglobulin E Tungau Debu Rumah pada Pasien Rinitis Alergi di Makasar. Departemen THT Fakultas Kedokteran Universitas Hasanudin, RS Dr. Wahidin Sudirohusodo. The Indonesian Journal of Medical Science 2008;1 (1) : 1-9.

6. Wistiani, Notoatmojo H. Hubungan Pajanan Alergen Terhadap Kejadian Alergi Pada Anak. Bagian Ilmu Kesehatan Anak Fakultas Kedokteran Universitas Diponegoro/ RSUP Dr. Kariadi. Sari Pediatri. 2011;13 (3) : 185-90.

7. Pawankar R, Canonica GW, Holgate S, Lockey R. WAO White Book on Allergy 2011-2012 [home page internet]:Executive Summary. Diunduh 9 desember 2012. http://www.worldallergy.org/UserFiles/file/ WAO-White-Book-on-Allergy_web.pdf

8. Purnomo. Faktor-Faktor Resiko Yang Berpengaruh Terhadap Kejadian Asma Bronkial Pada Anak. Studi Kasus Fakultas Kedokteran Universitas Diponegoro, Semarang: 2008. 